\title{
Implementation of Theory of Planned Behaviors to Participation and IVA Examination in Female Age Women
}

\author{
Tini Jufri, Katmini \\ ${ }^{1}$ Master of Public Health \\ Faculty of Health Sciences, \\ STRADA Indonesia \\ Email: \\ tinitasunadetasu@gmail.com
}

Received : October $4^{\text {nd }} 2021$

Accepted : October $15^{\text {rd }} 2021$

Published : November $27^{\text {th }} 2021$

\begin{abstract}
Cervical cancer is the leading cause of death in the world, with 311,365 cervical cancer deaths. recorded globally in 2018 . Cervical cancer is caused by the Human Papilloma Virus (HPV). This viral infection is often found in sexually active women who have multiple partners. Therefore, cervical cancer can be prevented by conducting early examination through Visual Acetate Inspection (IVA). The purpose of the literature review is to determine whether there is a relationship between theory of planned behavior and participation in IVA examinations in women of fertile age. The method uses Literature reviews from the Pubmed, Microsoft Academic, BASE and Google Scholar databases, published in 2015 to 2020, and manually selects and analyzes relevant articles. The results of the literature review show that of the 20 journals found and in accordance with the research questions, namely, 1 journal that discusses the Intention Relationship of the IVA test, 7 journals that discuss the Relationship of the IVA Test Behavior, 9 journals that discuss the Attitude Relationship of the IVA test, 3 journals that discuss the Relationship of Subjective Norms for the IVA test and from the 20 journals that were found active IVA examination, 4 journals and 16 journals that were not active performed the IVA examination. From the results of the analysis of the journal, it was found that there was a lack of knowledge and information about IVA tests so that women of childbearing age did not actively carry out IVA examinations, the importance of counseling and health education regarding early detection of cervical cancer, especially IVA tests, not only for women of childbearing age, but also for their husbands, so that they understand the importance of early detection of cervical cancer and can increase the intention, behavior, attitude and subjective norms towards the activity of the IVA test.
\end{abstract}

Keywords: IVA test, theory of planned behavior, HPV, literature review

Copyright @ 2021 IIK STRADA Indonesia All right reserved.

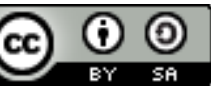

This is an open-acces article distributed under the terms of the Creative Commons AttributionShareAlike 4.0 International License. 


\section{INTRODUCTION}

$70 \%$ cervical cancer is caused by the Human Papilloma Virus (HPV). This viral infection is often found in women who are sexually active. While the triggering factors for cervical cancer are women who have multiple sexual partners, women who smoke, frequent washing of the vagina with anti-septic, low immunity, and use of contraceptive pills.

It is estimated that every day there are 40-45 new cases, 20-25 people die, meaning that every hour an estimated 1 woman dies of cervical cancer. This means that Indonesia will lose 600-750 productive women every month (Ministry of Health, 2015).

Therefore, cervical cancer can be prevented by early detection. The sooner it is known, the sooner treatment can be done before it gets worse. Early detection of cervical cancer can be done in primary health services such as Puskesmas through Visual Acetate Inspection (IVA). The equipment needed is quite simple and does not require expensive costs by observing a visual test using a 3-5\% acetic acid solution on the cervix and seeing the change in color. which occurs after basting which aims to see the presence of dysplasia cells as a part of the cervical cancer screening method (Anwar Mallongi, 2018)

Cervical cancer cases in Indonesia are caused by a lack of knowledge and awareness to do early detection so that most women who suffer from cervical cancer are found at an advanced stage and result in death because the cancer does not cause symptoms. And every woman has a risk for cervical cancer regardless of social, economic, status and age conditions (Pusdatin, 2015).

To prevent cervical cancer this prevention can be done by providing education to increase knowledge of conducting counseling and health education regarding early detection of cervical cancer, especially IVA test, not only for the mother group, but also for husbands, so that they understand the importance of early detection of cervical cancer in age couples. fertile, so that the husband can provide support to his wife for early detection of cervical cancer. In addition, the role of the husband as a decision maker will greatly affect the behavior of these fertile women in carrying out IVA examinations (Fatimah et al., 2018).

\section{METHOD}

The literature search was carried out by identifying all types of international and national articles regarding the Theory of Planned Behavior Relation to IVA Examination Participation in Women of Fertile Age The electronic data bases used were Base, Microsoft Academic, Pubmed, and Google Scholar with a search strategy using the PICO method (patient, intervention, comparasion and outcome) (Eriksen \& Frandsen, 2018). The keywords used in the literature search combine the following keywords: Theory Of Planned Behavior Against the Iva Test, Behavior against the Iva Test, the Behavior factor against the Iva Test. Search for articles is limited from 2015 to 2020 and manually select and analyze articles that are relevant or in accordance with the research. The article inclusion criteria are: (1) Relationship of Intention with IVA Examination (2) Relationship of Behavior with IVA Examination (3) Relationship of Attitude to IVA Examination (4) Relationship between 
Subjective Norms and Iva Test Examination (5) There is a relationship between Theory of Planned Behavior and the activity of IVA examination in women of fertile age, while the exclusion criteria are articles that are not free full text and are not relevant to the research question.

1. Literature Review Search Algorithm

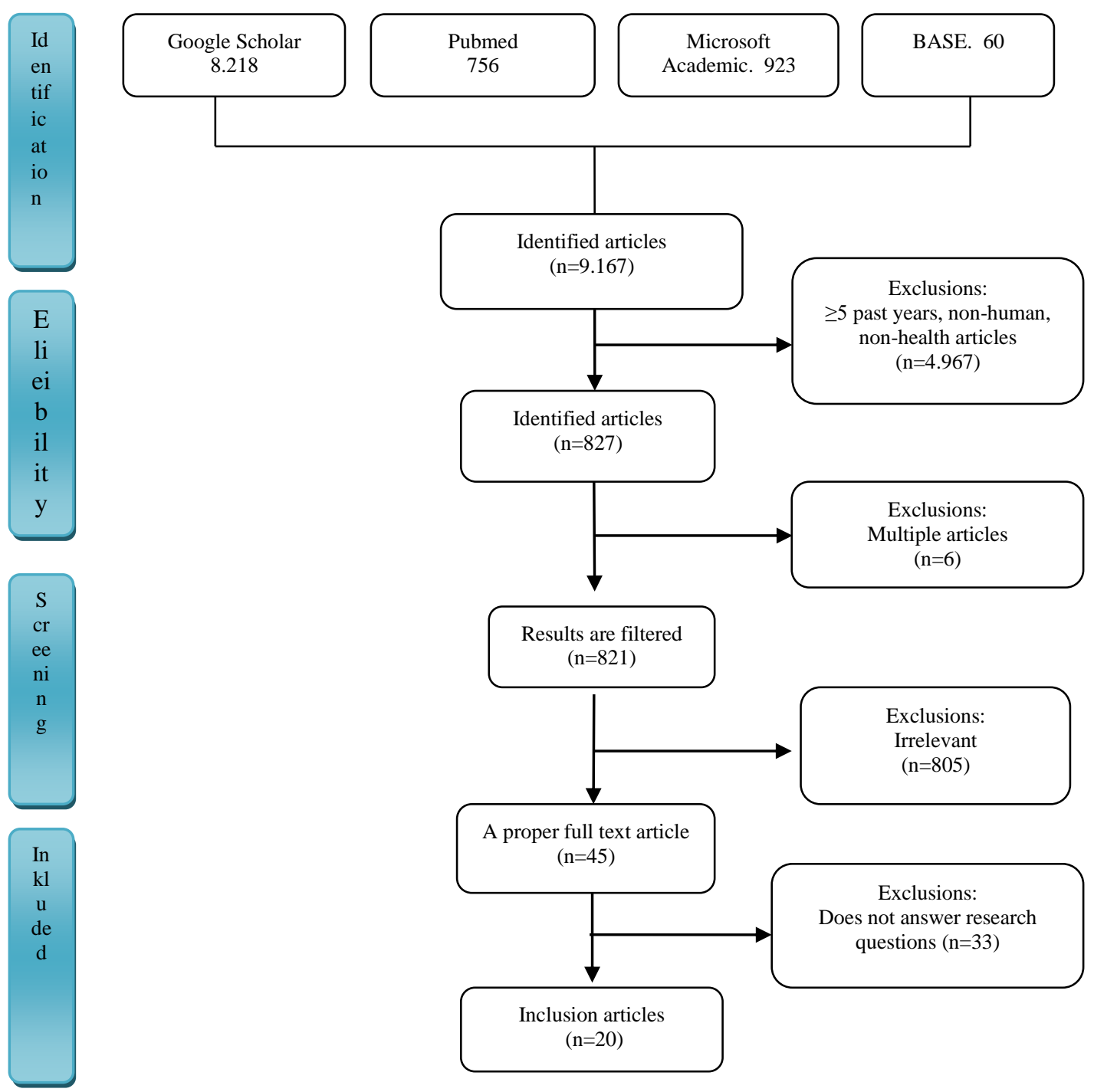

\section{RESULTS}

This literature review describes two articles that discuss the relationship between Theory of Planned Behavior and IVA examination participation in women of reproductive age. IVA, $66.7 \%$ had a non-supportive attitude, and $54.8 \%$ were not willing to take the test. The researcher explained that there was a significant relationship between knowledge and attitude with a P-value of 0,000. According to Fatimah et al., (2018) who conducted their research on 80 women of childbearing age. there is a relationship between intention, attitude, and subjective norms with the IVA test. $\mathrm{p}$ is 0.009 and the OR value is 8.83. there is a relationship between attitude and behavior IVA test with a $p$ value 
of 0.033 and an OR value of 5.11. There is a relationship between subjective norms and the behavior of the IVA test with a p value of 0.048 and an OR value of 4.11.

Another study conducted by Suci et al., (2020). Describing the results of his research that the factors that influence women of childbearing age in doing IVA are attitude $\mathrm{p}$ value 0.001 , cadre support $\mathrm{p}$ value 0.021 and source of information $p$ value 0.036 .

Harisnal et al., (2019). who conducted their research on 74 prostitutes and from the study showed that there was a relationship between husband support ( $\mathrm{p}$ value 0.017 and OR 5.429) and the role of officers ( $\mathrm{p}$ value 0.005 and OR 6.840) with the IVA test.

Fitria et al., (2019) conducted a study of 90 women of childbearing age. In this study, there was a relationship between knowledge of the fertility age of women on the visual examination of acetic acid (IVA test) and the IVA behavior test. The results of the analysis obtained $\mathrm{p}<0.05(0.003<0.05 \mathrm{X} 2$ count> X2 table $(11.553>5,991)$ with a contingency coefficient of 0.337 which means low closeness. Triana et al., (2018). conducted research on 39 respondents who had a good level of knowledge as many as 28 respondents $(21.4 \%)$ who had a high interest in IVA p-value $=0.001$ ( $\mathrm{p}<\mathrm{a} 0.05)$, of the 41 respondents who had a positive attitude, 27 respondents $(22,5 \%)$ who have high IVA interest p-value $=0.030(\mathrm{p}<\mathrm{a} 0.05)$.

Miftahil et al., (2019). conducted an experimental study of 110 women of childbearing age, that $60 \%$ of women of childbearing age had never done an IVA test. There is a relationship between knowledge level with $\mathrm{p}$ value 0.000 , attitude with $\mathrm{p}$ value 0.041 , access to information with $\mathrm{p}$ value 0.000 and husband support with $\mathrm{p}$ value 0.000 with IVA test. Variable that affects husband's support with $\mathrm{p}$ value 0,000 and Odds Ratio 46,693.

Masni et al., (2019). conducted a study on 212 women of fertile age who underwent IVA examinations as much as $42.5 \%$, variables related to the behavior of WUS in early detection were knowledge with a $\mathrm{p}$ value of 0.000 (POR: 5.082), husband's support with a $\mathrm{p}$ value of 0.001 (POR: 2.804), and health personnel support with p value 0.012 (POR: 2.424).

Ayu Wulandari et al., (2016). The results of the study, the most dominant factor determining IVA behavior sequentially, was the level of education ( $\mathrm{OR}=3.403)$, while other factors as protective factors included access to information $(\mathrm{OR}=0.272)$, support from health workers $(\mathrm{OR}=0.163)$, attitude $(\mathrm{OR}=0.104)$.

Tuty et al., (2018). From the results, it was found that most of the respondents did not perform the IVA examination. The bivariate analysis showed that there was a relationship between education, occupation, knowledge, sources of information and socio-economy with WUS who performed the IVA examination.

Laily et al., (2020). Shows that there is a relationship between perception and attitude indicating that more than half of respondents $66 \%$ have a positive perception in early detection of cervical cancer and positive for IVA. 
Putu et al., (2020) conducted a study on 104 women of childbearing age, there were subjective norm factors that influenced FAW's interest in detecting cervical cancer with a p-value of $0.016<0.05$ and educational and occupational factors did not affect FAW's interest in detecting cervical cancer.

Kartini et al., (2017) conducted a study on 72 couples of fertile age, this study showed knowledge of PUS about IVA examination. Most of the women of childbearing age who were positive had sufficient knowledge, while PUS who had negative attitudes mostly had less knowledge. There is a relationship between knowledge and attitudes about the visual inspection of Acetic Acid.

Lisda et al., (2019) with the participation of women in IVA examinations. And the results show that marital status, knowledge and attitudes are related to women's participation in IVA examinations. Attitude is the variable with the largest OR value, namely 20.4 and p value $<0.001$. Another study conducted by

Nonik et al., (2019) on 350 women of childbearing age. The factor associated with early detection of cervical cancer is knowledge ( $\mathrm{p}$-value $=0.003$ ). There is no relationship between attitude, trust and early detection of cervical cancer because there are other factors that are more influential. According to the research results, it is known that $68.9 \%$ did not do IVA because they did not know about IVA. Puji et al., (2019) conducted a study of 303 women of childbearing age based on the results of the study that there was a relationship between the level of knowledge and the IVA test, $\rho(0.048)$. There is no relationship between attitude and participation in the IVA test, $\rho(0.145)$.

Ummul et al., (2019) from 63 respondents who had a high level of knowledge, 27 respondents (42.9\%) made early detection using the VIA test method. Meanwhile, of the 38 respondents who had a low level of knowledge, 3 respondents (7.9\%) did early detection of cervical cancer using the VIA test method. From the results of the chi-square test analysis, it was found that $p=0.000$.

Sri et al., (2019). based on research results $(a=0.05)$ obtained $p$ value $=0.0001(p<0.05)$ there is a relationship between knowledge about cervical cancer and participation in doing the IVA test.

Sari et al., (2020) the level of knowledge was sufficient, namely $29(58.0 \%)$ and the behavior of the IVA examination was quite $30(60.0 \%)$. from the results of the sig value $0.000(<0.01)$. there is a relationship between the level of knowledge about IVA and the behavior of examining IVA at Village WUS.

Another study conducted by Riri et al., (2019) statistical tests obtained P value from five variables $<\square$ $(0.05$, there is a relationship between knowledge, attitudes, actions, information media, family support on early detection behavior of cervical cancer by examination iva 
Assess the quality of articles based on literature study findings

\begin{tabular}{|c|c|c|c|c|c|c|c|}
\hline No & Author & $\begin{array}{l}\text { Journal Name, } \\
\text { Vol, No, Year }\end{array}$ & Title & $\begin{array}{l}\text { Methods (sample design, } \\
\text { variable, analytical } \\
\text { instruments) }\end{array}$ & Research result & Conclusion & Database \\
\hline 1 & $\begin{array}{l}\text { Dini Mei } \\
\text { Widayanti, } \\
\text { Mochammad } \\
\text { Bagus } \\
\text { Qomaruddin } \\
\text { 'Dedi } \\
\text { irawandi }\end{array}$ & $\begin{array}{l}\text { Journal of } \\
\text { Public } \\
\text { Health } \\
\text { Research } \\
\text { DOI:10.4081/ } \\
\text { jphr.2020.1815 } \\
\text { 2020;9:1815 }\end{array}$ & $\begin{array}{c}\text { Mother's knowledge } \\
\text { and attitudes towards } \\
\text { Visual Acetate Acid } \\
\text { Inspection } \\
\text { tes tin Surabaya } \\
\text { Indonesia }\end{array}$ & $\begin{array}{l}\text { This study aims to } \\
\text { determine the relationship } \\
\text { between knowledge and } \\
\text { attitudes of mothers with } \\
\text { IVA test, using the } \\
\text { analytical and cross- } \\
\text { sectional study. Data were } \\
\text { obtained from mothers that } \\
\text { visited the family planning } \\
\text { section of the Maternal and } \\
\text { Child Health (MCH) } \\
\text { Center. Out of a total of } \\
184 \text { mothers, } 126 \text { samples } \\
\text { were chosen by purposive } \\
\text { sampling } \\
\text { technique. }\end{array}$ & $\begin{array}{l}\text { The results showed that } \\
59.5 \% \text { of respondents had } \\
\text { scarce knowledge on } \\
\text { IVAtests, } 66.7 \% \text { had } \\
\text { unsupportive attitudes } \\
\text { towards it, and } 54.8 \% \text { were } \\
\text { not willing to carry out the } \\
\text { tests. This study explains } \\
\text { that there is asignificant } \\
\text { relationship between } \\
\text { knowledge and attitude } \\
\text { with a P-value of } 0.000 \text {. }\end{array}$ & $\begin{array}{l}\text { In conclusion, } \\
\text { various factors } \\
\text { influence the } \\
\text { participation of } \\
\text { IVA examination, } \\
\text { namely lack of } \\
\text { knowledge, inability } \\
\text { to access } \\
\text { information, and } \\
\text { fear. }\end{array}$ & BASE \\
\hline 2 & $\begin{array}{l}\text { Fatimah } \\
\text { Dewi } \\
\text { Anggraeni, } \\
\text { Eva } \\
\text { Putriningru } \\
\mathrm{m}\end{array}$ & $\begin{array}{c}\text { Midwifery } \\
\text { Journal, } \\
\text { Vol. X, No. 02, } \\
2018\end{array}$ & $\begin{array}{l}\text { Analysis of factors } \\
\text { related to screening } \\
\text { behavior of dynamic } \\
\text { cancer detection } \\
\text { based on reasoned } \\
\text { action teory RAT) in } \\
\text { uskesmas sewoni. } \\
\text { Bantul, yogaakarta }\end{array}$ & $\begin{array}{l}\text { This type of research is } \\
\text { analytical survey research } \\
\text { using a cross sectional } \\
\text { approach. The population } \\
\text { in this study were women } \\
\text { of childbearing age aged } \\
20-50 \text { years as many as } \\
6,601 \text { people who lived in } \\
\text { the Work Area of I Sewon } \\
\text { Public Health Center } \\
\text { Bantul. The sampling } \\
\text { technique used purposive } \\
\text { sampling as many as } 80 \\
\text { women of childbearing age. } \\
\text { The data collection used } \\
\text { questionnaires and data the } \\
\text { analysis used logistic } \\
\text { regression analysis. }\end{array}$ & 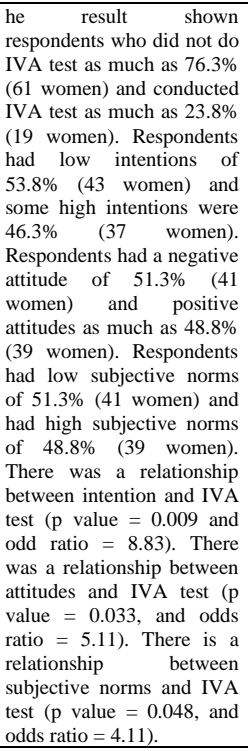 & $\begin{array}{l}\text { There is a } \\
\text { relationship between } \\
\text { intention, attitude, } \\
\text { and subjective norms } \\
\text { with IVA test. }\end{array}$ & Google Scholar \\
\hline 3 & $\begin{array}{l}\text { Suci } \\
\text { Nurjanah, } \\
\text { Asriwati } \\
\text { Jitasari. } \\
\text { Tarigan } \\
\text { Sibero }\end{array}$ & $\begin{array}{l}\text { Window } r \text { of } \\
\text { Health Jurnal } \\
\text { Kesehatan, Vol. } \\
\text { 3 No. } \\
\text { 3. } 2020: 218- \\
226\end{array}$ & $\begin{array}{l}\text { Factors Affecting A } \\
\text { Woman of } \\
\text { Childbearing Age to } \\
\text { Have a Visual } \\
\text { Inspection Test for } \\
\text { Acetic Acid (IVA) }\end{array}$ & $\begin{array}{l}\text { of Visual Acetate Acid } \\
\text { Inspection (IVA). The } \\
\text { scope of implementation } \\
\text { of Sapat Health Center IVA } \\
\text { in } 2019 \text { for women of } \\
\text { childbearing age aged 30- } \\
50 \text { is } 20.95 \% \text {. The purpose } \\
\text { of this } \\
\text { study was to determine the } \\
\text { factors that influence } \\
\text { women of childbearing age } \\
\text { in conducting the Acetic } \\
\text { Acid Visual } \\
\text { Inspection test. This type of } \\
\text { research is quantitative } \\
\text { with cross sectional } \\
\text { approach. The population is } \\
\text { all women of childbearing } \\
\text { age aged 30-50 years as } \\
\text { many as } 3240 \text { people. The } \\
\text { sample of this research is } \\
97 \text { respondents with } \\
\text { Proposional Random } \\
\text { Sampling technique. Data } \\
\text { analysis used univariate, } \\
\text { bivariate (Chi Square test), } \\
\text { and multivariate analysis } \\
\text { (multiple te logistic } \\
\text { regression tests). }\end{array}$ & $\begin{array}{l}\text { The results showed that } \\
\text { factors influencing women } \\
\text { of childbearing age in } \\
\text { conducting IVA were } \\
\text { attitudes p value } 0.001 \text {, } \\
\text { cadre support p value } \\
0.021 \text { and sources of } \\
\text { information p value } 0.036 . \\
\text { While the factors that have } \\
\text { no effect are knowledge, } \\
\text { husband's support, and } \\
\text { perception. The most } \\
\text { dominant factor influencing } \\
\text { was cadre support with an } \\
\text { OR value of } 14,144 \text { (95\% } \\
\text { CI = 1501-133,286). The } \\
\text { conclusion of this study is } \\
\text { that women of childbearing } \\
\text { age in conducting IVA tests } \\
\text { are influenced by attitudes, } \\
\text { cadre support and } \\
\text { information. }\end{array}$ & $\begin{array}{l}\text { It is recommended } \\
\text { that Puskesmas, } \\
\text { especially health } \\
\text { workers, be able to } \\
\text { work closely with } \\
\text { cadres and across } \\
\text { sectors in developing } \\
\text { cadres as an effort to } \\
\text { support IVA health } \\
\text { promotion so that the } \\
\text { coverage of IVA tests } \\
\text { in the area of } \\
\text { Puskesmas Sapat's } \\
\text { technical support } \\
\text { units can be carried } \\
\text { out } \\
\text { thoroughly. }\end{array}$ & Google Scholar \\
\hline
\end{tabular}




\begin{tabular}{|c|c|c|c|c|c|c|c|}
\hline 4 & Harisnal & $\begin{array}{l}\text { Jurnal } \\
\text { Kesehatan } \\
\text { Vol- 55. } 2019 \\
156-160\end{array}$ & $\begin{array}{l}\text { the contributing } \\
\text { factor in iva } \\
\text { examination }\end{array}$ & $\begin{array}{l}\text { Type of thus research is a } \\
\text { cross-sectional descriptive } \\
\text { analytic design with a } \\
\text { sample of } 74 \text { women of } \\
\text { childbearing age aged 15- } \\
49 \text { years in } \\
\text { the working area of the } \\
\text { Kolok community health } \\
\text { center with a probability } \\
\text { sampling technique } \\
\text { with proportional random } \\
\text { sampling. This research } \\
\text { was conducted on } 9 \text { to } 25 \\
\text { January } 2019 \text {. Data } \\
\text { collection is carried out by } \\
\text { kuisioner and observation } \\
\text { and analysis with the chi- } \\
\text { square test }\end{array}$ & $\begin{array}{l}\text { The results of univariate } \\
\text { analysis shows that } 55.4 \% \\
\text { are positive, } 63.5 \% \\
\text { husband's support, } 59.5 \% \\
\text { good health workers and } \\
70.3 \% \text { there is no visual } \\
\text { inspection of acetic acid } \\
\text { tests. The } \\
\text { results of the bivariate } \\
\text { analysis shows that there is } \\
\text { a correlationship between } \\
\text { husband support (p value } \\
0.017 \text { and OR (5.429) and } \\
\text { the role of officers (p value } \\
0.005 \text { and OR } 6.840 \text { ) with a } \\
\text { visual inspection of acetic } \\
\text { acid tests }\end{array}$ & $\begin{array}{l}\text { It can concluded that } \\
\text { role of health workers } \\
\text { has big influence } \\
\text { toward examining } \\
\text { inspection visual } \\
\text { acetic acid test in the } \\
\text { working area of } \\
\text { community } \\
\text { health centre Kolok }\end{array}$ & $\begin{array}{l}\text { Microsoft } \\
\text { Academic }\end{array}$ \\
\hline 5 & $\begin{array}{c}\text { Fitria Ika } \\
\text { Wulandari, } \\
\text { MAngelina, } \\
\text { F } \\
\text { Nuwwaaridy } \\
\text { a }\end{array}$ & $\begin{array}{c}\text { International } \\
\text { Respati Health } \\
\text { Conference } \\
\text { (IRHC) [2019] }\end{array}$ & $\begin{array}{c}\text { Relationshi Of } \\
\text { Reeproductive } \\
\text { Womens Knowlegde } \\
\text { On Visual Inspection } \\
\text { Of Aceticacid (IVA } \\
\text { Test) With IVA test } \\
\text { Behavior }\end{array}$ & $\begin{array}{l}\text { The method in this study } \\
\text { using Qualitative } \\
\text { Analytical, where the } \\
\text { population is all } \\
\text { reproductive women age in } \\
\text { the Gunting village } \\
\text { Wonosari Klaten districts } \\
\text { with } 90 \text { of sample } \\
\text { reproductive women with } \\
\text { probability sampling } \\
\text { technique by means of } \\
\text { proportional stratified } \\
\text { random sampling, research } \\
\text { samstruments using the } \\
\text { inslosed questionnaire } \\
\text { encled asing univariate and } \\
\text { bivariate analysis. }\end{array}$ & $\begin{array}{l}\text { Based on data analysis of } \\
\text { respondents who are } \\
\text { knowledgeable enough as } \\
\text { many as } 32 \text { people }(34.4 \%) \\
\text { and the majority of } \\
\text { respondents did not do as } \\
\text { many as } 81 \text { people } \\
(90.0 \%) \text {. In the } \\
\text { study there is a relationship } \\
\text { of fertility women age } \\
\text { knowledge on visual } \\
\text { inspection of acetic acid } \\
\text { (IVA test) with IVA } \\
\text { behaviour test. }\end{array}$ & 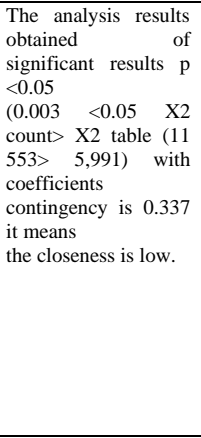 & Google Scholar \\
\hline 6 & $\begin{array}{l}\text { Triana } \\
\text { Indrayani } \\
\text { S.ST.M.Kes. } \\
\text {,Ns.Naziyah, } \\
\text { S.Ke.,M.Kep } \\
\text {.Rahmawati }\end{array}$ & $\begin{array}{l}\text { JAKHKJ Vol. } \\
\text { 4, No. 2, } 2018\end{array}$ & $\begin{array}{l}\text { The Relationship } \\
\text { between Knowledge } \\
\text { and Attitudes of } \\
\text { Fertile Age Women } \\
\text { Against the Intention } \\
\text { of Conducting a Test } \\
\text { at the Jatinegara } \\
\text { District Health Center }\end{array}$ & $\begin{array}{l}\text { This study used a cross } \\
\text { sectional approach. The } \\
\text { sampling technique used a } \\
\text { random sampling technique } \\
\text { with a total sample of } 62 \\
\text { women of childbearing age } \\
\text { in the Jatinegara District } \\
\text { Health Center who were } \\
\text { married. Data collection } \\
\text { was carried out at the } \\
\text { Jatinegara District } \\
\text { Puskesmas used a } \\
\text { questionnaire. }\end{array}$ & $\begin{array}{l}39 \text { respondents who had a } \\
\text { good level of knowledge } \\
\text { were } 28 \text { respondents } \\
(21.4 \%) \text { who had a high } \\
\text { interest in IVA p-value = } \\
0.001(\mathrm{p}<\mathrm{a} 0.05) \text {, of the } 41 \\
\text { respondents who had a } \\
\text { positive attitude, } 27 \\
\text { respondents }(22.5 \%)) \text { who } \\
\text { have high IVA interest p- } \\
\text { value }=0.030(\mathrm{p}<\mathrm{a} 0.05) .\end{array}$ & $\begin{array}{l}\text { There is a } \\
\text { relationship between } \\
\text { knowledge and } \\
\text { attitudes of women of } \\
\text { childbearing age } \\
\text { towards interests } \\
\text { perform an IVA. It is } \\
\text { hoped that this } \\
\text { research can increase } \\
\text { interest in doing IVA } \\
\text { in women of age } \\
\text { fertility that was } \\
\text { previously low } \\
\text { becomes high, for } \\
\text { example by providing } \\
\text { socialization about its } \\
\text { importance } \\
\text { IVA examination. }\end{array}$ & Google Scholar \\
\hline 7 & $\begin{array}{l}\text { Miftahil } \\
\text { Fauza, } \\
\text { Aprianti, } \\
\text { Azrimaidaliz } \\
\text { a }\end{array}$ & $\begin{array}{l}\text { Indonesian } \\
\text { Journal of } \\
\text { Health } \\
\text { Promotion Vol. } \\
14 \text { / No. 1/ } \\
\text { January } 2019\end{array}$ & $\begin{array}{l}\text { Factors Associated } \\
\text { with Cervical Cancer } \\
\text { Early Detection } \\
\text { Methods } \\
\text { IVA at Puskesmas } \\
\text { Kota Padang }\end{array}$ & $\begin{array}{l}\text { This research is an } \\
\text { explanatory research with a } \\
\text { cross-sectional approach, } \\
\text { conducted from February to } \\
\text { October 2018. The } \\
\text { population of this study } \\
\text { were fertile age women } \\
\text { who visited Alai Health } \\
\text { Center and Pegambiran } \\
\text { Health Center with size } \\
\text { sample of } 110 \\
\text { respondents. Consecutive } \\
\text { sampling method was } \\
\text { employed to select the } \\
\text { respondent. } \\
\text { collection was conducted } \\
\text { by interview using a } \\
\text { questionnaire. Data were } \\
\text { analyzed by ChiSquare } \\
\text { statistical } \\
\text { test and logistic regression } \\
\text { with } \\
\text { a confidence level of } 95 \% \text {. }\end{array}$ & $\begin{array}{l}\text { The results of the study } \\
\text { showed that } 60 \% \text { of } \\
\text { respondents had never } \\
\text { detected IVA test. The } \\
\text { results of the statistical test } \\
\text { showed that there was a } \\
\text { significant relationship } \\
\text { between th level of } \\
\text { knowledge with p value } \\
0,000 \text {, attitude with p value } \\
0.041 \text { access to } \\
\text { information with } \\
\text { p value } 0,000 \text { and husband } \\
\text { support with p value } 0,000 \\
\text { and the IVA test. The } \\
\text { results of multivariate } \\
\text { analysis showed that the } \\
\text { most dominant variables } \\
\text { affected the participation of } \\
\text { women in cancer early } \\
\text { detection through IVA } \\
\text { tests, was husband's } \\
\text { support with p value } 0,000 \\
\text { and Odds Ratio } 46,693 \text {, } \\
\text { which means respondents } \\
\text { who supported by husbands } \\
\text { were likely to } \\
\text { do IVA test } 46 \text { times } \\
\text { compared to those not } \\
\text { supported. Therefore the } \\
\text { dissemination } \\
\text { information was not only } \\
\text { provided to women but also } \\
\text { men including husbands in } \\
\text { order to motivate women } \\
\text { for IVA test. }\end{array}$ & $\begin{array}{l}\text { Cervical cancer, IVA } \\
\text { test, knowledge, } \\
\text { attitude, fertile age } \\
\text { women, husband } \\
\text { support }\end{array}$ & Google Scholar \\
\hline 8 & $\begin{array}{l}\text { Masni, } \\
\text { Syamsul } \\
\text { Bahri Riva, } \\
\text { Nurhapipa }\end{array}$ & $\begin{array}{l}\text { Excellent } \\
\text { Midwifery } \\
\text { jurnal Vol } 2 . \\
\text { No. } 2 \\
2019\end{array}$ & $\begin{array}{l}\text { The Behavior of } \\
\text { Women of Fertile } \\
\text { Age (Wus) in Early } \\
\text { Detection } \\
\text { Cervical Cancer } \\
\text { Using the IVA } \\
\text { Method in } 2018\end{array}$ & $\begin{array}{l}\text { Cross sectional study } \\
\text { design. Sample of } 212 \\
\text { people. The sampling } \\
\text { procedure was proportional } \\
\text { random sampling method, } \\
\text { data collection used a } \\
\text { questionnaire and data } \\
\text { analysis was carried out by } \\
\text { univariate, bivariate with }\end{array}$ & $\begin{array}{l}\text { The results showed that the } \\
\text { proportion of women who } \\
\text { did early detection of } \\
\text { cervical cancer using the } \\
\text { IVA method was } 42.5 \% \text {. } \\
\text { value } 0.001 \text { (POR: } 2.804 \text { ), } \\
\text { and support for health } \\
\text { workers with p value } 0.012 \\
\text { (POR: } 2.424 \text { ) and not }\end{array}$ & $\begin{array}{l}\text { It is hoped that there } \\
\text { will be collaboration } \\
\text { between Puskesmas } \\
\text { and Cross Sectors, } \\
\text { Women's } \\
\text { Organizations, and } \\
\text { professional } \\
\text { organizations within } \\
\text { increase knowledge }\end{array}$ & Google Scholar \\
\hline
\end{tabular}




\begin{tabular}{|c|c|c|c|c|c|c|c|}
\hline & & & & $\begin{array}{l}\text { chi square and multivariate } \\
\text { tests. Data analysis was } \\
\text { performed by univariate, } \\
\text { bivariate with chi square } \\
\text { test, and multivariate with } \\
\text { multiple logistic regression } \\
\text { tests. }\end{array}$ & $\begin{array}{l}\text { exposed to counfonding } \\
\text { variables. It can be } \\
\text { concluded that women of } \\
\text { childbearing age whose } \\
\text { knowledge } \\
\text { approximately } 5 \text { are } \\
\text { more likely will not } \\
\text { undergo IVA examinations } \\
\text { than mothers with good } \\
\text { knowledge. }\end{array}$ & $\begin{array}{l}\text { about IVA } \\
\text { examinations so that } \\
\text { mothers want to do } \\
\text { IVA examinations. } \\
\text { To religious leaders } \\
\text { and community } \\
\text { leaders together to } \\
\text { provide support for } \\
\text { the husband to } \\
\text { provide support to his } \\
\text { wife to do IVA } \\
\text { examination. }\end{array}$ & \\
\hline 9 & $\begin{array}{l}\text { Ayu } \\
\text { Wulandari, } \\
\text { Sri } \\
\text { Wahyunings } \\
\text { ih, Ferdiana } \\
\text { Yunita }\end{array}$ & $\begin{array}{l}\text { JK Unila } \mid \\
\text { Volume } 2 \mid \\
\text { Nomor } 2 \mid \text { Juli } \\
2018\end{array}$ & $\begin{array}{l}\text { Factors Related to } \\
\text { Behavior of Visual } \\
\text { Inspection of Acetic } \\
\text { Acid (IVA) } \\
\text { ofChildbearing } \\
\text { Women in Puskesmas } \\
\text { Sukmajaya } 2016\end{array}$ & $\begin{array}{l}\text { An analytical observational } \\
\text { study with cross-sectional } \\
\text { design was used and } 146 \\
\text { respondents were chosen as } \\
\text { the sample by simple } \\
\text { random sampling. } \\
\text { Questionnaires } \\
\text { were used to identify VIA } \\
\text { behavior as dependent } \\
\text { variable and predisposing } \\
\text { factor (age, knowledge } \\
\text { level, education level, } \\
\text { attitude, employment } \\
\text { status, socio-economic } \\
\text { level), enabling factor } \\
\text { (information access, } \\
\text { distance affordability, } \\
\text { expense and } \\
\text { affordability) actor (family } \\
\text { reinforcing factor } \\
\text { support, health worker's } \\
\text { support, health cadre's } \\
\text { support, counseling) as an } \\
\text { independent variable. }\end{array}$ & $\begin{array}{l}\text { Logistic regression analysis } \\
\text { showed that dominant } \\
\text { factor determining VIA } \\
\text { behavior was education } \\
\text { level (OR }=3.403) \text {, while } \\
\text { the other as protective } \\
\text { factors such as information } \\
\text { access }(\mathrm{OR}=0.272) \text {, health } \\
\text { worker's support } \\
(\mathrm{OR}=0.163) \text {, attitude (OR } \\
=0.104) \text { and income of } \\
\text { childbearing women } \\
(\mathrm{OR}=0.045) .\end{array}$ & $\begin{array}{l}\text { health worker's } \\
\text { support }(\mathrm{OR}=0.163) \text {, } \\
\text { attitude }(\mathrm{OR}=0.104) \\
\text { and income of } \\
\text { childbearing women } \\
(\mathrm{OR}=0.045) \text { An } \\
\text { enhacement of health } \\
\text { promotion program is } \\
\text { needed, including } \\
\text { counseling and } \\
\text { socialization for high } \\
\text { educated women. }\end{array}$ & Google Scholar \\
\hline 10 & $\begin{array}{l}\text { Tuty } \\
\text { Yanuarti. } \\
\text { Mareta Evi } \\
\text { Dela }\end{array}$ & $\begin{array}{l}\text { Journal } \\
\text { Between } \\
\text { Midwifery Vol. } \\
1 \text { No. 4. } 2018\end{array}$ & $\begin{array}{l}\text { Factors Related to } \\
\text { Women's Behavior } \\
\text { Age of SIA Fertile } \\
\text { Willing to Do IVA } \\
\text { Examination }\end{array}$ & $\begin{array}{l}\text { Research methodology } \\
\text { used is quantitative } \\
\text {.Population in this research } \\
\text { is the women of the fertile } \\
\text { that } \\
\text { visit puskesmas kec } \\
\text {.Pondok gede bekasi timur } \\
\text { on the } 08 \text { may } 2017 \text { with } \\
\text { the sample of the some } 50 \\
\text { people. }\end{array}$ & $\begin{array}{l}\text { Of the results of the } \\
\text { analysis univariat obtained } \\
\text { the majority of respondents } \\
\text { not have a iva } 60 \% \text {, low } \\
\text { education } 58 \% \text {, work } 64 \\
\% \text {, knowledge good and } \\
\text { quite } 36 \% \text {, a source of } \\
\text { information from the media } \\
58 \% \\
\text { and socioeconomic \& lt; } \\
\text { ukm } 52 \%\end{array}$ & $\begin{array}{l}\text { Analysis bivariat } \\
\text { obtained the } \\
\text { connection between } \\
\text { education, work, } \\
\text { knowledge, a source } \\
\text { of information and } \\
\text { social the economy } \\
\text { by wus who performs } \\
\text { examination iva }\end{array}$ & Google Scholar \\
\hline 11 & $\begin{array}{l}\text { Laily Prima } \\
\text { Monica1, } \\
\text { Maria Ulfa }\end{array}$ & $\begin{array}{l}\text { Journal of } \\
\text { Nurses and } \\
\text { Midwifery } \\
\text { DOI: } 10.26699 \\
/ \\
\text { jnk.v7i1.ART.p } \\
044-049 \\
2020\end{array}$ & $\begin{array}{l}\text { The Correlation of } \\
\text { the Perception of } \\
\text { Early Detection } \\
\text { Cervical Cancer with } \\
\text { Attitude to do Visual } \\
\text { Inspection with } \\
\text { Acetic Acid }\end{array}$ & $\begin{array}{l}\text { The research design used } \\
\text { correlational } \\
\text { design with a cross- } \\
\text { sectional approach. } \\
\text { The study population is } 30 \\
\text { respondents and the sample } \\
\text { consisted of } 27 \text { respondents } \\
\text { using purposive sampling } \\
\text { technique. Data were } \\
\text { analyzed using Spearman } \\
\text { rank }\end{array}$ & $\begin{array}{l}\text { The research data showed } \\
\text { that there was a } \\
\text { relationship between the } \\
\text { level of perception of } \\
\text { mothers about cervical } \\
\text { cancer and the attitude of } \\
\text { mothers to carry out the } \\
\text { IVA test (Visual Inspection } \\
\text { with Acetic Acid) p value = } \\
0,000 \text {, so the p value = } \\
0,000<0.05 \text { while } r= \\
0.678 \text {. }\end{array}$ & $\begin{array}{l}\text { The relationship of } \\
\text { perception with } \\
\text { attitude shows that } \\
\text { more than half of the } \\
\text { respondents } 66 \% \\
\text { have a positive } \\
\text { perception } \\
\text { in early detection of } \\
\text { cervical cancer and } \\
\text { they are positive } \\
\text { about IVA (Visual } \\
\text { Inspection with } \\
\text { Acetic Acid). W }\end{array}$ & $\begin{array}{l}\text { Microsoft } \\
\text { Academic }\end{array}$ \\
\hline 12 & $\begin{array}{l}\text { Putu Indah } \\
\text { Sintya Dewi }\end{array}$ & $\begin{array}{l}\text { Journal for } \\
\text { Quality in } \\
\text { Public Health } \\
\text { Vol. 3, No. 2, } \\
\text { May 2020, pp: } \\
\text { 575-583 } \\
\text { DOI:10.30994/j } \\
\text { qph.v3i2.107 }\end{array}$ & $\begin{array}{l}\text { The Analysis of } \\
\text { Factors Affecting } \\
\text { Interest in Fertile Age } \\
\text { Women in } \\
\text { Performing Early } \\
\text { Detection of Cervical } \\
\text { Cancer at Community } \\
\text { Health Center } \\
\text { Kubutambahan I } \\
\text { Buleleng Regency- } \\
\text { Bali }\end{array}$ & $\begin{array}{l}\text { This study aimed to } \\
\text { analyze the influence of the } \\
\text { characteristics of FAW, } \\
\text { attitudes and subjective } \\
\text { norms of FAW on the } \\
\text { interest of early detection } \\
\text { of cervical cancer at } \\
\text { Community Health Center } \\
\text { Kubutambahan I. This type } \\
\text { of research was an } \\
\text { observational analytic } \\
\text { cross-sectional design } \\
\text { study. The population in } \\
\text { this study FAW who } \\
\text { visited at Community } \\
\text { Health Center } \\
\text { Kubutambahan I with a } \\
\text { sample of } 104 \text { FAW } \\
\text { sampling technique that } \\
\text { was simple random } \\
\text { sampling. Bivariate data } \\
\text { analysis used chi square } \\
\text { statistical tests and } \\
\text { multivariate analysis } \\
\text { used logistic regression. }\end{array}$ & $\begin{array}{l}\text { The results of this study } \\
\text { that there is a knowledge } \\
\text { factor influencing interest } \\
\text { with a p-value of } 0.023 \\
<0.05 \text { attitude factor } \\
\text { influencing interest with a } \\
\text { p-value of } 0.023 \\
<0.05 \text {, there are subjective } \\
\text { norm factors influencing } \\
\text { FAW interest } \\
\text { in detecting cervical cancer } \\
\text { with p -value } 0.016<0.05 \\
\text { and } \\
\text { educational and } \\
\text { occupational factors do not } \\
\text { affect FAW interest in } \\
\text { detecting cervical cancer } \\
\text { with p-value } 0.05 \text {. The } \\
\text { conclusion of this study did } \\
\text { not significantly influence } \\
\text { education and employment } \\
\text { factors with a p value> } \\
0.05 \text {. While knowledge, } \\
\text { attitudes and subjective } \\
\text { norms are factors that } \\
\text { influence } \\
\text { significantly with a p value } \\
<0.05\end{array}$ & $\begin{array}{l}\text { The dominant factor } \\
\text { influencing FAW's } \\
\text { interest in early } \\
\text { detection of cervical } \\
\text { cancer is subjective } \\
\text { norm. }\end{array}$ & BASE \\
\hline 13 & Kartini & $\begin{array}{l}\text { HIJP: Health } \\
\text { Information } \\
\text { Journal of } \\
\text { research } \\
\text { Vol 9, } \\
\text { No. 2, } 2017\end{array}$ & $\begin{array}{l}\text { The Relationship } \\
\text { between Knowledge } \\
\text { and Attitudes of } \\
\text { Mother about Visual } \\
\text { Inspection of Acetic } \\
\text { Acid at Puskesmas } \\
\text { Poasia, Kendari City }\end{array}$ & $\begin{array}{l}\text { This is cross-sectional } \\
\text { analysis, the sample of } \\
\text { research was in PUS, } 72 \text { in } \\
\text { the Center for Health } \\
\text { Poasia, Kendari Region. } \\
\text { The data collection method } \\
\text { was an information and } \\
\text { attitudes questionnaire on } \\
\text { the VIA study. Chi-square } \\
\text { testing was performed for } \\
\text { analysis of results. }\end{array}$ & $\begin{array}{l}\text { The results showed that } \\
\text { most of } \\
\text { PUS' knowledge of the } \\
\text { VIA test was in the lack of } \\
\text { knowledge group in } \\
\text { Puskemas Poasia in } \\
\text { Kendari District. The key } \\
\text { attitudes of the PUS } \\
\text { towards the IVA test were } \\
\text { in the negative category at } \\
\text { the Poasia Health Centre, in }\end{array}$ & $\begin{array}{l}\text { In Puskesmas Poasia, } \\
\text { City of Kendari, there } \\
\text { is a connection } \\
\text { between mother's } \\
\text { information about } \\
\text { vision inspection } \\
\text { with acetic acid. }\end{array}$ & $\begin{array}{l}\text { Microsoft } \\
\text { Academic }\end{array}$ \\
\hline
\end{tabular}


Implementation of Theory of Planned Behaviors.....

\begin{tabular}{|c|c|c|c|c|c|c|c|}
\hline & & & & & $\begin{array}{l}\text { Kendari District. Many } \\
\text { reproductive women have } \\
\text { ample knowledge of their } \\
\text { positive attitudes, while the } \\
\text { majority of reproductive- } \\
\text { age women have less } \\
\text { knowledge of adverse } \\
\text { attitudes. }\end{array}$ & & \\
\hline 14 & $\begin{array}{l}\text { Lisda } \\
\text { Widianti } \\
\text { Longgupa }\end{array}$ & $\begin{array}{l}\text { Smart Midwife } \\
\text { Journal } \\
\text { Vol. 1 No. 3: } \\
\text { August 2019| } \\
\text { Thing. 151 - } \\
\text { 158 }\end{array}$ & $\begin{array}{l}\text { Determinants of } \\
\text { Participation of } \\
\text { Fertile Women in } \\
\text { IVA Examination in } \\
\text { Poso District }\end{array}$ & $\begin{array}{l}\text { The design of this study } \\
\text { was cross-sectional. The } \\
\text { samples were taken from } \\
\text { women who received } \\
\text { counseling about cervical } \\
\text { cancer during } 2016 \text { at } \\
\text { districts Health Center by } \\
\text { using proportional random } \\
\text { sampling. Overall } \\
\text { respondents were } 198 \\
\text { women. }\end{array}$ & 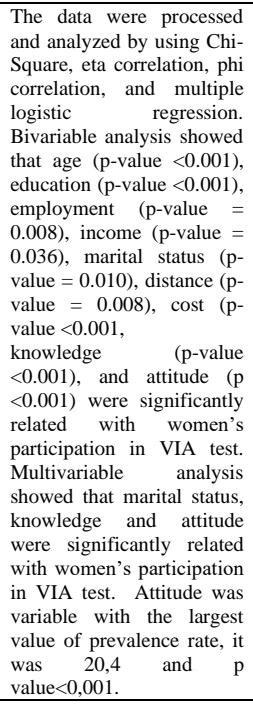 & $\begin{array}{l}\text { The conclusions that } \\
\text { can be taken in this } \\
\text { study includes socio- } \\
\text { demographic factors } \\
\text { were associated with } \\
\text { women's } \\
\text { participation in VIA } \\
\text { test, except parity; } \\
\text { the cost has weak } \\
\text { relationship with } \\
\text { women's participation } \\
\text { in VIA harge has } \\
\text { test; knowledge has } \\
\text { fairly strong } \\
\text { relationship with } \\
\text { women's participation } \\
\text { in VIA test; attitude } \\
\text { has fairly strong } \\
\text { relationship with } \\
\text { women's participation } \\
\text { in VIA test and } \\
\text { attitude is the most } \\
\text { dominant factor } \\
\text { related with women's } \\
\text { participation in VIA } \\
\text { test }\end{array}$ & Google Scholar \\
\hline 15 & $\begin{array}{l}\text { Nonik Ayu } \\
\text { Wantini, } \\
\text { Novi } \\
\text { Indrayani }\end{array}$ & $\begin{array}{l}\text { Journal of } \\
\text { Nurses and } \\
\text { Midwifery, } \\
\text { Volume 6, } \\
\text { Number 1, } \\
\text { April 2019, p. } \\
\text { 027-034 }\end{array}$ & $\begin{array}{l}\text { Early Detection of } \\
\text { Cervical Cancer by } \\
\text { Visual Inspection of } \\
\text { Acetic Acid (IVA) }\end{array}$ & $\begin{array}{l}\text { Until 2016, the coverage of } \\
\text { VIA in Indonesia was } \\
4.34 \% \text { which was still far } \\
\text { from the national target of } \\
10 \% \text { at the end of } 2015 \text {. } \\
\text { The design used analytical } \\
\text { survey research with cross } \\
\text { sectional design. The } \\
\text { research was conducted on } \\
\text { March } 19 \text { to May } 42018 \text {. } \\
\text { The sample was all women } \\
\text { aged } 19-49 \text { years who } \\
\text { visited Kalasan Public } \\
\text { Health Center, lived in } \\
\text { Kalasan Sub-District, and } \\
\text { met the inclusion and } \\
\text { exclusion criteria. }\end{array}$ & $\begin{array}{l}\text { The sample was } 350 \text { people } \\
\text { selected by consecutive } \\
\text { sampling technique. The } \\
\text { instruments used } \\
\text { questionnaires and data } \\
\text { collection techniques with } \\
\text { interviews. } \\
\text { The data analysis used } \\
\text { fisher exact test. } \\
\text { Knowledge of cervical } \\
\text { cancer was mostly in the } \\
\text { low category (97.4\%). A } \\
\text { positive attitude towards } \\
\text { early detection } \\
\text { of cervical cancer was } \\
96.3 \% \text {. } 80.3 \% \\
\text { believed that cervical } \\
\text { cancer would heal if it was } \\
\text { found early. } 92.3 \% \\
\text { respondents } \\
\text { didn't do VIA test in the } \\
\text { last } 3 \text { years. Factors related } \\
\text { to } \\
\text { early detection of cervical } \\
\text { cancer are knowledge (p- } \\
\text { value =0.003). }\end{array}$ & $\begin{array}{l}\text { There isn't any } \\
\text { correlation between } \\
\text { attitudes, beliefs and } \\
\text { early detection of } \\
\text { cervical cancer } \\
\text { because there are } \\
\text { other factors that are } \\
\text { more influential. } \\
\text { According to the } \\
\text { results of } \\
\text { the study, } 68.9 \% \\
\text { didn't do VIA } \\
\text { because they didn't } \\
\text { know about VIA. }\end{array}$ & Google Scholar \\
\hline 16 & $\begin{array}{l}\text { puji wahyuni } \\
\text { Christin } \\
\text { HiyanaTung } \\
\text { ga } \\
\text { Dewi } \\
\text { puji wahyuni } \\
\text { RibkhaIthaId } \\
\text { hayanti }\end{array}$ & $\begin{array}{l}\text { Midwifery } \\
\text { And Nursing } \\
\text { Research } \\
\text { (MANR) } \\
\text { Journal Vol.1 } \\
\text { No.1 March } \\
2019\end{array}$ & $\begin{array}{l}\text { Determinat Factors } \\
\text { Corellated with IVA } \\
\text { Test } \\
\text { Among Couple of } \\
\text { Childbearing Age }\end{array}$ & $\begin{array}{l}\text { Type of research used in } \\
\text { this research Analitic. } \\
\text { Cross-sectional design } \\
\text { used. Univariate analysis to } \\
\text { know the frequency } \\
\text { distribution of each } \\
\text { variable. Bivariate analysis } \\
\text { using Spearman Rank test. } \\
\text { The population of } 303 \\
\text { EFA, Determining the } \\
\text { sample with slovin to } 75 \\
\text { respondents. The sampling } \\
\text { technique uses the } \\
\text { proportional stratified } \\
\text { random sampling, and the } \\
\text { way sampling by } \\
\text { computerization. }\end{array}$ & $\begin{array}{l}\text { Based on the results of } \\
\text { research enough knowledge } \\
\text { level of } 56 \% \text { ( } 42 \\
\text { respondents). Attitudes that } \\
\text { agree with the participation } \\
\text { of the IVA test is } 62.7 \% \\
\text { (47 respondents), husband } \\
\text { support IVA test that is } \\
54.7 \% \text { (41 respondents), } \\
\text { health support worker IVA } \\
\text { test that is } 64 \% \text { (48 } \\
\text { respondents), respondents } \\
\text { get access to information } \\
53.3 \% \text { (40 respondents), } \\
\text { respondents who are } \\
\text { willing to follow the IVA } \\
\text { test is } 65.3 \% \text { (49 } \\
\text { respondents). In Spearman } \\
\text { Rank test there is a } \\
\text { relationship between } \\
\text { knowledge level with IVA } \\
\text { test participation, } \rho(0.048) \text {. } \\
\text { There is no relationship } \\
\text { between attitude with IVA } \\
\text { test participation, } \rho(0,145) \text {. } \\
\text { There is a relationship } \\
\text { between the support of the } \\
\text { husband with the } \\
\text { participation of the IVA } \\
\text { test, } \rho(0.000) \text {. There is no } \\
\text { correlation between the } \\
\text { support of pen } \\
\text { health personnel with the } \\
\text { participation of the IVA } \\
\text { test, } \rho \text { (0407). }\end{array}$ & $\begin{array}{l}\text { Based the results of } \\
\text { the study is expected } \\
\text { Midwives support } \\
\text { and improve } \\
\text { counseling about the } \\
\text { IVA test, respondents } \\
\text { can increase of } \\
\text { knowledge about } \\
\text { IVA test information } \\
\text { and husband always } \\
\text { support the wife. }\end{array}$ & Pubmed \\
\hline
\end{tabular}


Implementation of Theory of Planned Behaviors.....

\begin{tabular}{|c|c|c|c|c|c|c|c|}
\hline 17 & $\begin{array}{l}\text { Ummul } \\
\text { Qura } \\
\text {, Jumriani } \\
\text { Ansar, Dian } \\
\text { Sidik } \\
\text { Arsyad, } \\
\text { Indra } \\
\text { Dwinata, } \\
\text { Muh. Ikhsan } \\
\text { Suriah }\end{array}$ & $\begin{array}{l}\text { Epidemiology } \\
\text { and Society } \\
\text { Health Review } \\
\text { Vol 1 No1 } \\
2019\end{array}$ & $\begin{array}{l}\text { The Determinants of } \\
\text { Cervical Cancer } \\
\text { Early Detection } \\
\text { Behaviour with VIA } \\
\text { Test Method in } \\
\text { Visitors of Policlinic } \\
\text { "KIA-KB" in Kassi- } \\
\text { Kassi Public Health } \\
\text { Centre of Kota } \\
\text { Makassar. Indonesia }\end{array}$ & $\begin{array}{l}\text { The research was } \\
\text { observational analytical } \\
\text { research with cross } \\
\text { sectional study design. The } \\
\text { population of the study was } \\
\text { all women of fertile couple } \\
\text { that visited } \\
\text { Policlinic KIA-KB in } \\
\text { Kassi-Kassi Public Health } \\
\text { Center and lived within the } \\
\text { coverage area of Kassi- } \\
\text { Kassi Public Health Center, } \\
\text { which amounted to } 135 \\
\text { women. The samples were } \\
101 \text { women that were } \\
\text { collected by using } \\
\text { accidental sampling } \\
\text { technique. }\end{array}$ & $\begin{array}{l}\text { The results } \text { showed that } \\
\text { there was a relation } \\
\text { between knowledge } \\
(\mathrm{p}=0.000), \quad \text { attitude } \\
(\mathrm{p}=0.005) \text {, husband support } \\
(\mathrm{p}=0.000) \text {, as well as health } \\
\text { worker } \\
\text { support ( } \mathrm{p}=0.000) \text { and early } \\
\text { detection behaviour by } \\
\text { using IVA test method. }\end{array}$ & $\begin{array}{l}\text { Meanwhile, there was } \\
\text { no relation between } \\
\text { education and early } \\
\text { detection behaviour } \\
\text { by using IVA test } \\
\text { method. There should } \\
\text { be proactive and } \\
\text { creative actions from } \\
\text { health workers in } \\
\text { improving the } \\
\text { knowledge of the } \\
\text { targets and } \\
\text { their husbands about } \\
\text { early detection of } \\
\text { cervical cancer. }\end{array}$ & Pubmed \\
\hline 18 & $\begin{array}{l}\text { Sari } \\
\text { Wulandari }\end{array}$ & $\begin{array}{l}\text { Jurnal } \\
\text { Maternity and } \\
\text { Neonatal } \\
\text { vol } 2 \text { no } 6 \\
2019\end{array}$ & $\begin{array}{l}\text { Fertile knowledge } \\
\text { about the women } \\
\text { participation in } \\
\text { cervical cancer with } \\
\text { do iva test at } \\
\text { puskesmas kabupaten } \\
\text { tambusai rokan the } \\
2018 \text { year }\end{array}$ & $\begin{array}{l}\text { Cervical cancer is a type of } \\
\text { cancer occurring in areas, } \\
\text { cervix and is the main } \\
\text { cause of death among } \\
\text { women. around the world } \\
274.000 \text { estimated deaths } \\
\text { occur each year as a result } \\
\text { of this disease, with an } \\
\text { estimated around percent of } \\
\text { new cases } 89 \text {. in } \\
\text { developing countries }\end{array}$ & $\begin{array}{l}\text { The main cause of cervical } \\
\text { cancer is human } \\
\text { papillomavirus ( ) hpv as } \\
\text { the main cause of death } \\
\text { among women worldwide } \\
\text { in rescuing women that the } \\
\text { victim, cervical cancer one } \\
\text { of them is by effort to early } \\
\text { detection methods visual } \\
\text { inspection with acetic acid } \\
\text { ( iva ), a method of iva is } \\
\text { practical, screening method } \\
\text { simple, and cheap. }\end{array}$ & $\begin{array}{l}\text { High sensitive The } \\
\text { purpose of this } \\
\text { research to know the } \\
\text { fertile woman } \\
\text { knowledge of } \\
\text { cervical cancer with } \\
\text { participation in doing } \\
\text { iva test center } \\
\text { tambusai rokan } \\
\text { upstream years 2018. } \\
\text { The methodology } \\
\text { quantitative research } \\
\text { survey design } \\
\text { analytic used }\end{array}$ & Google Scholar \\
\hline 19 & $\begin{array}{l}\text { Sri } \\
\text { Handayani } \\
\text {,Viantika, } \\
\text { Kusumasari }\end{array}$ & $\begin{array}{l}\text { Journal of } \\
\text { Health } \\
\text { Polytechnic of } \\
\text { the Indonesian } \\
\text { Ministry of } \\
\text { Health, } \\
\text { Pangkalpinag } \\
\text { Vol. 8, No.1, } \\
\text { June 2020 }\end{array}$ & $\begin{array}{l}\text { Relationship of } \\
\text { Knowledge Level } \\
\text { About VIA Sari } \\
\text { Purwanti } \\
\text { With VIA } \\
\text { Examination } \\
\text { Behavior }\end{array}$ & $\begin{array}{l}\text { This research is descriptive } \\
\text { analytic with cross } \\
\text { sectional design. The study } \\
\text { population of all women of } \\
\text { childbearing age in the } \\
\text { village of Selo, Sidomulyo } \\
\text { Bambanglipuro Village, } \\
\text { Bantul of } 82 \mathrm{r} \text { women of } \\
\text { childbearing. Samples were } \\
\text { taken by purposive } \\
\text { sampling of } 50 \text { women of } \\
\text { childbearing age. Data } \\
\text { collection using a } \\
\text { questionnaire. Data } \\
\text { analysis using the Kendall- } \\
\text { Tau correlation test. }\end{array}$ & $\begin{array}{l}\text { he level of knowledge of } \\
\text { the majority of women of } \\
\text { childbearing age were } \\
\text { sufficient }(29.0 \%) \text { and the } \\
\text { majority of } \text { VIA } \\
\text { examinations were } 30 \\
(60.0 \%) \text { Kendall-tau } \\
\text { correlation test results } \\
\text { obtained sig value of } 0,000 \\
(<0.01)\end{array}$ & $\begin{array}{l}\text { on: There is a } \\
\text { significant } \\
\text { relationship between } \\
\text { the level of } \\
\text { knowledge about } \\
\text { VIA with VIA } \\
\text { examination behavior } \\
\text { in WUS Sidomulyo } \\
\text { Village } \\
\text { Bambanglipuro } \\
\text { Bantul. }\end{array}$ & $\begin{array}{l}\text { Microsoft } \\
\text { Academic }\end{array}$ \\
\hline 20 & $\begin{array}{l}\text { Riri } \\
\text { Maharan } \\
\text { dan Chikma } \\
\text { Vitria Syah }\end{array}$ & $\begin{array}{l}\text { Vol. 14, No. 1, } \\
\text { April 2019: 1 - } \\
\text { 59| }\end{array}$ & $\begin{array}{l}\text { Early detection } \\
\text { behavior of cervical } \\
\text { cancer with IVA } \\
\text { examination by } \\
\text { women of } \\
\text { childbearing age } \\
\text { (WUS) in Sorek 1 } \\
\text { village in the working } \\
\text { area of the Pangkalan } \\
\text { Kuras district health } \\
\text { center, Pelalwan } \\
\text { patent }\end{array}$ & $\begin{array}{l}\text { The type of this research is } \\
\text { quantitative analytics, with } \\
\text { cross sectional design. The } \\
\text { population } 2960 \text { with the } \\
\text { sample } 156 \text { is by using } \\
\text { random } \\
\text { sampling technique. The } \\
\text { analysis used is univariate } \\
\text { and bivariate analysis by } \\
\text { Chi Square test. }\end{array}$ & $\begin{array}{l}\text { Based on the result of } \\
\text { the research, most of the } \\
\text { respondents do the } \\
\text { behavior of early detection } \\
\text { of cervical cancer with IVA } \\
\text { test as much as } \\
35(77,6 \%) \text {, respondents } \\
\text { with knowledge as low as } \\
103(66,0 \%)(\mathrm{POR}=3,039 ; \\
95 \% \text { CI } 1,401-6,590) \\
\text { respondents } \\
\text { with negative attitude as } \\
\text { much as } 88(56,4 \%) \text { (POR } \\
=2,362 ; 95 \% \text { CI } 1,095- \\
5,094) \text {. respondents who } \\
\text { did not act as } \\
\text { much as } 118(75,6 \%)(\mathrm{POR} \\
=2,694 ; 95 \% \text { CI } 1,198- \\
6,060) \text {, respondents who } \\
\text { never received information } \\
\text { as much } \\
\text { as79 (50,6\%) (POR = } \\
2,378 ; 95 \% \text { CI } 1,085- \\
5.212) \text { and respondents } \\
\text { who did not get family } \\
\text { support as much as } 93 \\
(59.6 \%) \text { (POR = 2,419; } \\
95 \% \text { CI } 1,124-5,203) \text {. }\end{array}$ & $\begin{array}{l}\text { Based on statistical } \\
\text { test were obtained P } \\
\text { value of five } \\
\text { variables < } \\
\text { (0.05), there is } \\
\text { correlation between } \\
\text { knowledge, attitude, } \\
\text { action, information } \\
\text { media, family support } \\
\text { toward behavior of } \\
\text { early detection of } \\
\text { cervical cancer with } \\
\text { IVA test. The } \\
\text { suggestionexpected } \\
\text { for woman of } \\
\text { childbearing age } \\
\text { increase to dVA } \\
\text { awareness to do IVA } \\
\text { for early detection of } \\
\text { cervical cancer. }\end{array}$ & $\begin{array}{l}\text { Microsoft } \\
\text { Academic }\end{array}$ \\
\hline
\end{tabular}




\section{DISCUSSION}

\section{Relationship of Intention with IVA Examination}

intention or intention is a cognitive and conative representation, if the individual does not have the intention to carry out a behavior, the individual tends not to carry out that behavior (Ajzen, 1975). Research (Fatimah et al., 2018). obtained p value of 0.009. The significance value is below 0.05, which means there is a relationship between intention and the IVA test. Intent can predict the behavior of the IVA test, which means that women who have high intentions are willing to do the IVA test compared to women who have low intentions.

\section{Relationship of the IVA examination behavior}

According to the theory (Notoatmodjo, 2010), he must know in advance what the benefits of this behavior are for him. A person will do early detection of cervical cancer by IVA examination if he knows the ways and benefits for himself. What has been done by several studies, namely Sari et al., (2020), Riri et al., (2019), Fitria et al., (2019), Ummul et al., (2019), Masni et al., (2019) ). and Ayu et al., (2016). There is a relationship between iva examination and IVA test behavior. The factors that determine IVA behavior are the level of education, information, support of health workers, attitudes and income of WUS. women of childbearing age whose knowledge are more or less at risk will not undergo IVA examinations than mothers with good knowledge.

\section{Attitude Relationship with IVA Examination}

Individuals will form a belief about an object that will be assessed positively or negatively. Attitude is one of the predisposing factors that influence women in early detection of cervical cancer (Ajzen, 1991). Lisda et al. (2019), Putu et al., (2020) and Kartini et al., (2017) Fatimah et al., (2018), Dini et al., (2020) and Triana et al., (2018). Puji et al., (2019) and Nonik et al., (2019). respondents who have a negative attitude have a 3.8 times greater risk of having low IVA interest. research by Laily et al., (2020). It is known that the attitude of the mother in doing the IVA test towards almost all $(77.8 \%)$ had a positive attitude towards the IVA examination.

\section{Relationship between Subjective Norms and Iva Test Examination.}

According to Fishbein and Ajzen (2010), subjective norms are a function based on beliefs called normative beliefs, namely beliefs about the agreement and / or disagreement of a person or group that is important for individuals to a behavior According to Fatimah et al., (2018) and Putu et al., (2020). women of childbearing age who have positive subjective norms are influenced by the people closest to the respondent so that it provides encouragement for early detection of cervical cancer.

\section{of cervical cancer.The activity of IVA examination in fertile age women}

Of the 20 journals found and in accordance with the research questions, namely, 1 journal that discusses the Relationship of Intention with the IVA Examination, 7 journals that discuss the Relationship of IVA Examination Behavior, 9 journals that discuss the Relationship between Attitudes and the IVA Examination, 3 journals that discuss Relationship between Subjective Norms 
and IVA Examination and from these 20 journals, 4 journals were found to be active in IVA examination and 16 who were inactive did IVA examination. because higher education is easier to receive information and has more knowledge about IVA examinations.

\section{CONCLUSION}

This review literature shows that what causes women of childbearing age not to take IVA examinations are those who are poorly educated with a lack of information and knowledge so that the mother does not know the benefits of the IVA examination, the importance of knowledge about early detection of cervical cancer so that it can increase intention, behavior, attitudes and norms. subjective to the IVA test.

\section{SUGGESTION}

Increase the knowledge of conducting counseling and health education regarding early detection of cervical cancer, especially IVA tests, not only for the group of mothers, but also for husbands, so that they understand the importance of early detection of cervical cancer.In addition, the role of the husband as a decision maker will greatly influence the behavior of women women in doing IVA examination.

\section{REFERENCES}

Nonik Ayu Wantini, Novi Indrayani (2018). Jurnal Ners dan Kebidanan Deteksi Dini Kanker Serviks dengan Inspeksi Visual Asam Asetat (IVA). http://jnk.phb.ac.id/index.php/jnk. DOI:10.26699/jnk.v6i1.ART.p027-034

Harisna. (2019). the contributing factor in iva examination Jurnal Kesehatam 2019156 160.AttributionNonCommercial-ShareAlike 4.0 International. http://dx.doi.org/10.35730/jk.v0i0.440

Laily Prima Monica1, Maria Ulfa. (2020). The Correlation of the Perception of Early Detection Cervical Cancer with Attitude to do Visual Inspection with Acetic Acid DOI:10.26699/jnk.v7i1.ART.p044-049

Riri Maharan \& Chikma Vitria Syah. (2019). Perilaku deteksi dini kanker Serviks dengan pemeriksaan IVA oleh wanita usia subur (WUS) didesa sorek satu diwilaya kerja puskesmas pangkalan kuras kabu paten Pelalwan Vol. 14, No. 1, April $2019: 1$ - 59.

Dini Mei Widayanti, Mochammad Bagus Qomaruddin, Dedi Irawandi. (2020). Mother's knowledge and attitudes towards Visual Acetate Acid Inspection test in Surabaya Journal of Public Health Research 2020; 9:1815

Miftahil Fauza, Aprianti, Azrimaidaliza. (2019). Faktor yang Berhubungan dengan Deteksi Dini Kanker Serviks Metode IVA di Puskesmas Kota Padang Jurnal Promosi Kesehatan Indonesia Vol. 14 / No. 1 / Januari 2019

Puji Wahyuni. Christin HiyanaTunggaDewi, RibkhalthaIdhayanti. (2019). Determinat Factors Corellated with IVA Test Among Couple of Childbearing Age. MIDWIFERY AND NURSING RESEARCH (MANR) JOURNAL Vol.1 No.1 March 2019

http://ejournal.poltekkes-smg.ac.id/ojs/index.php/MANR

Wulandari, Wahyuningsih, Yunita I (2016). Faktor-faktor yang Berhubungan dengan Perilaku Pemeriksaan IVA JK Unila | Volume 2| Nomor 2 | Juli 2018 | 94 
Sri Wulandari .(2019). Hubungan Pengetahuan Wanita Usia Subur Tentang Kanker Serviks

Dengan Keikutsertaan Dalam Melakukan IVA Test Di Puskesmas TambusaiKabupaten Rokan Hulu Tahun 2018 Jurnal Maternity and Neonatal vol 2 no 6.

Ummul Qura, Jumriani Ansar, Dian Sidik Arsyad, Indra Dwinata, Muh. Ikhsan Suriah. (2019). The Determinants of Cervical Cancer Early Detection Behaviour with VIA Test Method in Visitors of Policlinic "KIA-KB" in Kassi-Kassi Public Health Centre of Kota Makassar. Epidemiology and Society Health Review Vol 1 Nol 2019

Suci Nurjanah, Asriwati, Jitasari Tarigan Sibero. (2020). Faktor Yang Mempengaruhi Wanita Usia Subur Dalam Melakukan Tes Inspeksi Visual Asam Asetat (IVA) Window of Health : Jurnal Kesehatan, Vol. 3 No. 3 (Juli, 2020) : 218-226

Fatimah Dewi Anggraeni, Eva Putriningrum(2018). Analysis of factors related to screening behavior of dynamic cancer detection based on reasoned action teory RAT) in uskesmas sewoni. Bantul, yogaakarta. Jurnal Kebidanan 10 (02) 103 - 205 http : /www.journal.stikeseub.ac.id

Lisda Widianti Longgupa. .(2019). Determinan Keikutsertaan Wanita Usia Subur dalamPemeriksaan IVA di Kabupaten Poso. Jurnal Bidan Cerdas http://jurnal.poltekkespalu.ac.id/index.php/JBC/. 151 - 158

Sari Purwanti, Sri Handayani, dan RR Viantika Kusumasari. (2020). Hubungan Tingkat Pengetahuan Tentang IVA Dengan Perilaku Pemeriksaan IVA .Vol. 8, No.1, Juni 2020 63. 2620-6234

Fitria Ika Wulandari, M Angelina. F Nuwwaaridya, H Desti1, T M Sudiro.(2019). Relationshi Of Reeproductive Womens Knowlegde On Visual Inspection Of Aceticacid (IVA Test) With IVA test Behavior. International Respati Health Conference (IRHC) [Juli 2019]

Putu Indah Sintya Dewi. (2020). The Analysis of Factors Affecting Interest in Fertile Age Women in Performing Early Detection of Cervical Cancer at Community Health Center Kubutambahan I Buleleng Regency-Bali. Journal for Quality in Public Health. DOI: 10.30994/jqph.v3i2.107

Kartini. (2017). Hubungan Pengetahuan dan Sikap Ibu tentang Pemeriksaan Inspeksi Visual Asam Asetat di Puskesmas Poasia Kota Kendari https://myjurnal.poltekkes kdi.ac.id/index.php/HIJP p-ISSN: 2083-0840|eISSN: 2622-5905 Volume 9, Nomor 2, Desember 2017

Masni, Syamsul Bahri Riva'i, Nurhapipa.(2019). Perilaku Wanita Usia Subur (Wus) Dalam Melakukan Deteksi Dini Kanker Leher Rahim Dengan Metode IVA Tahun 2018

Excellent Midwifery jurnal Vol 2. No. 22019

Triana Indrayani S.ST.M.Kes., Ns.Naziyah,S.Kep., M.Kep.Rahmawati. .(2018). Hubungan Pengetahuan dan SikapWanita Usia Subur Terhadap niat Melakukan test di Puskesmas Kecamatan Jatinegara JAKHKJ Vol. 4, No. 2, 2018 -ISSN: 2442-501x, e-ISSN: 2541-2892

Tuty Yanuarti. Mareta Evi Dela.(2018). Faktor-Faktor Yang Berhubungan Dengan Perilaku Wanita Usia SIA Subur Mau Melakukan Pemeriksaan IVA .Jurnal Antara Kebidanan Vol. 1 No. 4. 2018 ISSN : 2656-9167

Ajzen I. 1991. The Teory of Planned Behavior. University of Massachusetts at Amherst: Academic Press. Inc. Fishbein M, Ajzen I. 1975. Dan 2010 Belief, Attitude, Intention, and Behavior: New York:

WHO. 2014.dan 2018 Comprehensive Cervical Cancer Control A guide to essential practice. Australia:WHO Library Cataloguing in Publication Data. 